
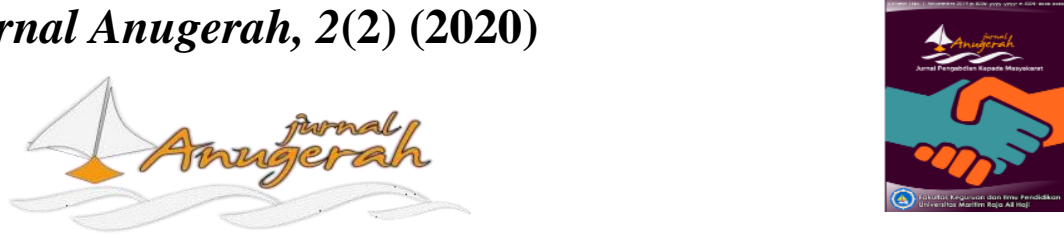

e-ISSN 2715-8179

https://ojs.umrah.ac.id/index.php/anugerah

\title{
Workshop Merancang Pembelajaran Daring Berbantuan Edmodo dan Cloud di Masa COVID-19 untuk KKG Gugus 02 Kranggan Mojokerto
}

\author{
Evangelista W L Palupi", Susanah, Shofan Fiangga, Dayat Hidayat, Masriyah \\ Jurusan Matematika \\ Universitas Negeri Surabaya, Surabaya, Jawa Timur 60231, Indonesia \\ *e-mail korespondensi: evangelistapalupi@unesa.ac.id \\ Pengiriman: tgl/bln/thn; Diterima: tgl/bln/thn; Publikasi: 30 November 2020 \\ DOI: https://doi.org/10.31629/anugerah.v2i2.2739
}

\begin{abstract}
Abstrak
Tujuan dari pengabdian kepada masyarakat ini adalah untuk memberikan pelatihan dalam merancang pembelajaran daring dengan memanfaatkan platform online Edmodo dan cloud kepada Kelompok Kerja Guru (KKG) Gugus 02 Kranggan Mojokerto. Hal ini dilatarbelakangi oleh permasalahan guru-guru dalam menavigasikan digital platform pembelajaran, memindahkan pembelajaran luring ke pembelajaran daring, serta mengorganisir tugas-tugas peserta didik. Metode yang digunakan dalam pelatihan ini yaitu ceramah/direct instruction dan demonstrasi yang dilaksanakan secara syncronous dan asyncronous. Peserta dalam kegiatan ini adalah guru-guru Sekolah Dasar (SD) KKG Gugus 02 Kranggan Mojokerto Jawa Timur. Instrumen yang digunakan dalam pengambilan data adalah angket/kuesioner. Angket ini digunakan untuk mengetahui wawasan dan persepsi awal peserta pelatihan terhadap pembelajaran daring yang telah mereka lakukan serta mengetahui wawasan dan persepsi mereka setelah mengikuti pelatihan. Berdasarkan hasil angket, workshop yang telah dilakukan memberikan dampak yang positif dan bermanfaat bagi guru-guru Sekolah Dasar di Krangga Mojokerto.
\end{abstract}

Kata kunci: Edmodo; pengabdian masyarakat; workshop

\begin{abstract}
The purpose of this community service is to provide training in designing online learning using the Edmodo online platform and the cloud to KKG Gugus 02 Kranggan Mojokerto. This is motivated by teacher problems in navigating digital learning platforms, moving offline learning to online learning, and managing student assignments. The method used in this training is direct lectures / instructions and demonstrations which are carried out synchronously and asynchronously. Participants in this activity were teachers of SD KKG Gugus 02 Kranggan, Mojokerto, East Java. The instrument used in data collection was a questionnaire. This questionnaire is used to find out the training participants' initial insights and perceptions of the online learning they have done and to find out their insights and perceptions after attending the training. Based on the results of the questionnaire, it was seen that most of the participants got clear and useful information from holding online learning workshops assisted by edmodo and the cloud.
\end{abstract}

Keywords: Edmodo; community service; workshop 


\section{JURNAL ANUGERAH, November 2020; Vol 2(2): 101 - 108 e-ISSN 2715-8179}

\section{Pendahuluan}

Pandemi Coronavirus 2019 (COVID-19) yang telah terjadi memiliki dampak yang begitu luas pada pendidikan global (Crawford, 2020). Virus yang mematikan dan menyebar dengan sangat cepat ini membuat setiap negara harus mampu bertahan dengan segala keterbatasan. Salah satu upaya yang dilakukan oleh seluruh negara termasuk Indonesia dengan himbauan dari organisasi Kesehatan dunia (WHO) adalah dengan menerapkan isolasi, karantina, dan pembatasan sosial. Pada sektor Pendidikan misalnya, Menteri Pendidikan Indonesia mengeluarkan surat Edaran Mendikbud Nomor 3 tahun 2020 dan Nomor 4 tahun 2020 tentang pencegahan COVID-19 pada satuan Pendidikan serta kebijakan pembelajaran jarak jauh sebagai upaya optimal dimasa pendemi, dan Nomor 36962/MPK.A/HK/2020 tentang pembelajaran secara daring dan bekerja dari rumah dalam rangka pencegahan penyebaran virus korona (Surat Edaran Mendikbud, 2020a; $2020 \mathrm{~b} ; 2020 \mathrm{c})$. Pembelajaran secara daring dilakukan untuk mengurangi interaksi secara langsung antara siswa maupun guru.

Pembelajaran daring sebenarnya telah muncul cukup lama dan digunakan oleh sebagian orang. Sebagai contohnya yaitu adanya Massive Open Online Courses (MOOCs), Coursera, atau Fedex yang membagikan dan menyelenggarakan perkuliahan oleh dosen dari berbagai universitas di dunia (Joksimović et al., 2018). Penyelenggaraan pembelajaran yang memanfaatkan koneksi internet ini memungkinkan dua orang atau lebih berinteraksi secara langsung tanpa harus bertemu. Pada pembelajaran daring ini, materi ajar, tugas, serta diskusi diberikan melalui platform digital atau melalui Learning Management system (LMS) yang dapat diakses menggunakan koneksi internet. Alkawiti (2017) dan Panyajamorn (2018) menjelaskan bahwa dalam mengembangkan pembelajaran daring terdapat beberapa komponen yang perlu diperhatikan yaitu (1) platform yang digunakan; (2) konten pembelajaran; (3) assessment pembelajaran. Platform yang digunakan berhubungan dengan LMS yang dipilih. Terdapat banyak alternatif platform online yang memiliki kelebihan dan kekurangan masing-masing. Guru dapat menentukan platform yang digunakan yang sesuai dengan tujuan pembelajaran. Konten pembelajaran merupakan materi-materi pembelajaran yang disusun dan dikembangkan secara online. Sedangkan assessment merupakan penilaian atau evaluasi hasil pembelajaran siswa saat atau setelah pembelajaran dilakukan.

Pelaksanaan pembelajaran daring di masyarakat faktanya terdapat beberapa kendala. Seperti yang dilansir oleh sejumlah surat kabar elektronik (Widyanuratikah, 2020; Widyo, 2020) mengemukakan bahwa melakukan pembelajaran daring tidaklah mudah. Terdapat beberapa kendala yang terjadi antara lain: (1) pembelajaran daring yang dilakukan hanya menekankan pada pemberian tugas dengan pengawasan orang tua; (2) kesulitan guru dalam merancang pembelajaran daring; (3) keterampilan guru dalam menggunakan teknologi informasi untuk daring belum cukup baik. Kendala merancang pembelajaran daring juga dialami oleh guru-guru yang tergabung dalam KKG Gugus 02 Kec. Kranggan Kota Mojokerto. Salah satu guru mengungkapkan kesulitannya dalam mengelola kelasnya dalam pembelajaran daring serta dalam menggunakan platform digital atau LMS untuk mengembangkan pembelajaran. Hal tersebut dikarenakan pengalaman mengakses platform online untuk pembelajaran masih kurang.

Salah satu platform online yang dapat digunakan oleh guru dalam melaksanakan pembelajaran daring adalah Edmodo. Selain penggunaannya yang mudah, tampilannya yang menarik juga cocok digunakan bagi pendidik di tingkat sekolah dasar maupun menengah. Pada platform Edmodo, guru dapat mempersiapkan dan mengorganisasikan kegiatan belajar meliputi materi pembelajaran dalam file atau video dengan mudah. Evenddy dan Hamer (2016) juga mengungkapkan bahwa Edmodo dapat dioperasikan oleh guru/dosen, siswa, dan orang tua sehingga memungkinkan untuk memposting berbagai tugas dan prestasi belajar siswa, topik diskusi actual, video, janji temu, dan juga jejak pendapat siswa yang terkait proses belajar mengajar. Selain itu, guru juga dapat menghubungkan materi dengan sumber belajar lainnya baik itu video pada youtube (Astuti \& Febrian, 2019), maupun aplet-aplet pada website. Selain itu, salah satu platform penyimpanan eksternal yang dapat digunakan oleh guru-guru adalah cloud. Guru-guru yang 
memiliki cloud dapat membantu mereka dalam menyimpan file file pembelajaran dengan baik serta menggunakannya dengan mudah dalam merancang pembelajaran daring.

Telah banyak studi atau kajian tentang penggunaan Edmodo dalam pembelajaran disekolah. Ariani et al. (2017) pada penelitiannya mengembangkan pembelajaran digital menggunakan Edmodo untuk siswa sekolah dasar dan menyimpulkan bahwa Edmodo menjadi hal yang menjanjikan untuk melibatkan siswa dalam proses pembelajaran. Selain itu, Trust (2017) dengan penelitiannya menemukan bahwa guru memiliki rasa termotivasi dan memberdayakan diri dalam melakukan inovasi pembelajaran setelah menggunakan Edmodo dalam pembelajaran disekolah. Berdasarkan uraian diatas, tim pengabdian merasa perlu untuk mengadakan pelatihan merancang pembelajaran daring dengan memanfaatkan Edmodo dan Cloud untuk membantu guru-guru di KKG gugus $02 \mathrm{Kec}$.Kranggan kota Mojokerto dalam melaksanakan pembelajaran daring dimasa pandemic COVID-19.

\section{Metode}

Metode yang digunakan pada kegiatan pengabdian kepada masyarakat ini adalah pelatihan untuk guru-guru Sekolah Dasar KKG Gugus 02 Kranggan Mojokerto, Jawa Timur. Pelatihan ini dilakukan dalam rangka memberikan wawasan mengenai cara merancang pembelajaran daring dengan menggunakan salah satu Learning management System (LMS) yaitu Edmodo. Pelatihan ini dilaksanakan secara sistematis secara online menggunakan platform Google Meeting pada hari rabu tanggal 9 September 2020. Pelaksanaan pelatihan ini dilakukan dengan dua pendekatan yaitu ceramah/ direct instruction dan demonstrasi. Pendekatan ceramah dilakukan pada saat penyampaian materi inti secara langsung oleh narasumber secara syncronious. Sedangkan demonstrasi dilakukan secara syncronious untuk awal materi pengenalan Edmodo oleh narasumber dan dilanjutkan secara asyncronious menggunakan LMS Edmodo untuk pendampingan eksplorasi tugas-tugas yang mendalam oleh peserta. Materi yang dipaparkan meliputi: 1) merancang rencana pembelajaran moda daring; 2) pengenalan Edmodo dan pembuatan kelas edmodo; 3) membuat tugas dan kuis pada edmodo; 4) pemanfaatan manajemen file menggunakan library dan cloud.

Evaluasi kegiatan dilakukan menggunakan kuesioner secara online menggunakan google form. Pada awal pelatihan, kuesioner awal diberikan untuk mengetahui wawasan awal peserta dalam menghadapi pembelajaran daring yang telah dilalui. Setelah pelatihan, diberikan kuesioner online juga digunakan untuk mengetahui persepsi dan wawasan dari guru-guru setelah mendapat pelatihan Edmodo. Teknik analisis data secara kualitatif berdasarkan hasil data yang diperoleh dan penarikan kesimpulan ditentukan berdasarkan hasil analisis data kualitatif.

\section{Hasil dan Pembahasan}

Kegiatan workshop merancang pembelajaran daring berbantuan Edmodo dan Cloud kepada guruguru KKG Mojokerto telah sukses diselenggarakan dalam satu minggu mulai 9-16 sepetember 2020 secara daring (synchronous dan asynchronous) menggunakan aplikasi Edmodo dan Google Meeting. Kegiatan ini diikuti oleh 37 guru SD yang tergabung dalam KKG Mojokerto. Pelatihan diawali dengan pemberian materi mengenai Rencana Pelaksanaan Pembelajaran (RPP) daring dan memperkenalkan platform belajar online apa saja yang dapat digunakan terutama Edmodo (Gambar 1). Selanjutnya, guru-guru diperkenalkan secara mendalam dengan salah satu Learning management System (LMS) yaitu Edmodo. Penjelasan dan demonstrasi serta praktik pengelolaan disampaikan kedalam tiga bagian yaitu: (1) pembuatan kelas pada Edmodo serta fitur-fiturnya; (2) Membuat tugas dan kuis pada edmodo untuk menunjang assessment pembelajaran; (3) mengorganisasikan file pada Edmodo dengan menggunakan menu library. 


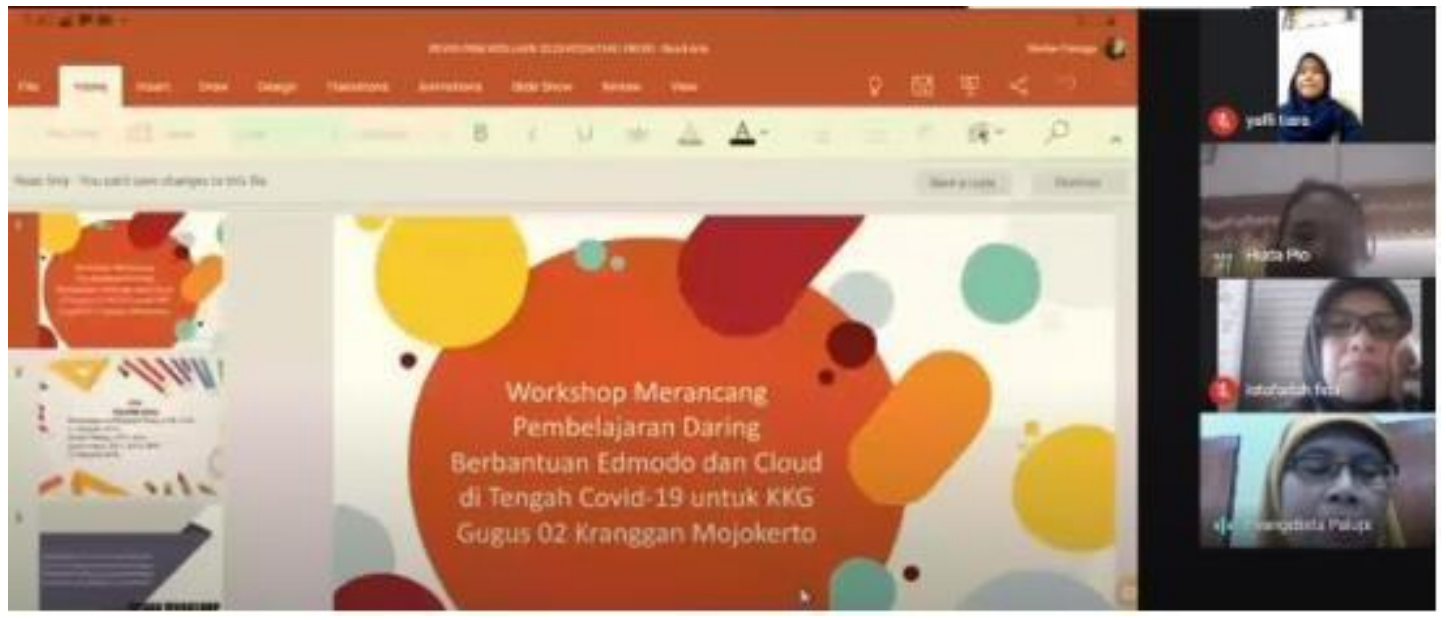

Gambar 1. Penyampaian materi oleh tim

Sesaat sebelum pelaksanaan pelatihan, peserta diwajibkan mengisi daftar hadir sekaligus angket yang bertujuan untuk mengetahui persepsi guru dan kondisi saat ini berkaitan dengan pembelajaran daring. Berdasarkan angket tersebut diketahui bahwa sebanyak sekitar 90,7\% peserta pelatihan belum pernah menggunakan LMS edmodo dalam pembelajaran daring dan 9,3\% sudah pernah menggunakan LMS edmodo (Gambar 2).

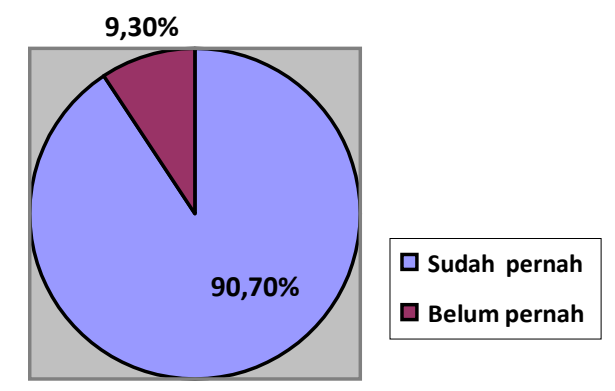

Gambar 2. Diagram persentase penggunaan Edmodo

Secara umum, peserta pelatihan merasa puas dengan workshop yang diberikan dan merasa pelatihan yang diikuti bermanfaat bagi tugas mereka sebagai seorang pendidik. Kepuasan peserta diukur berdasarkan respon peserta pelatihan terhadap angket dengan skala likert yang diberikan pada akhir pelatihan. Respon peserta pelatihan dapat dilihat pada gambar dibawah ini. 


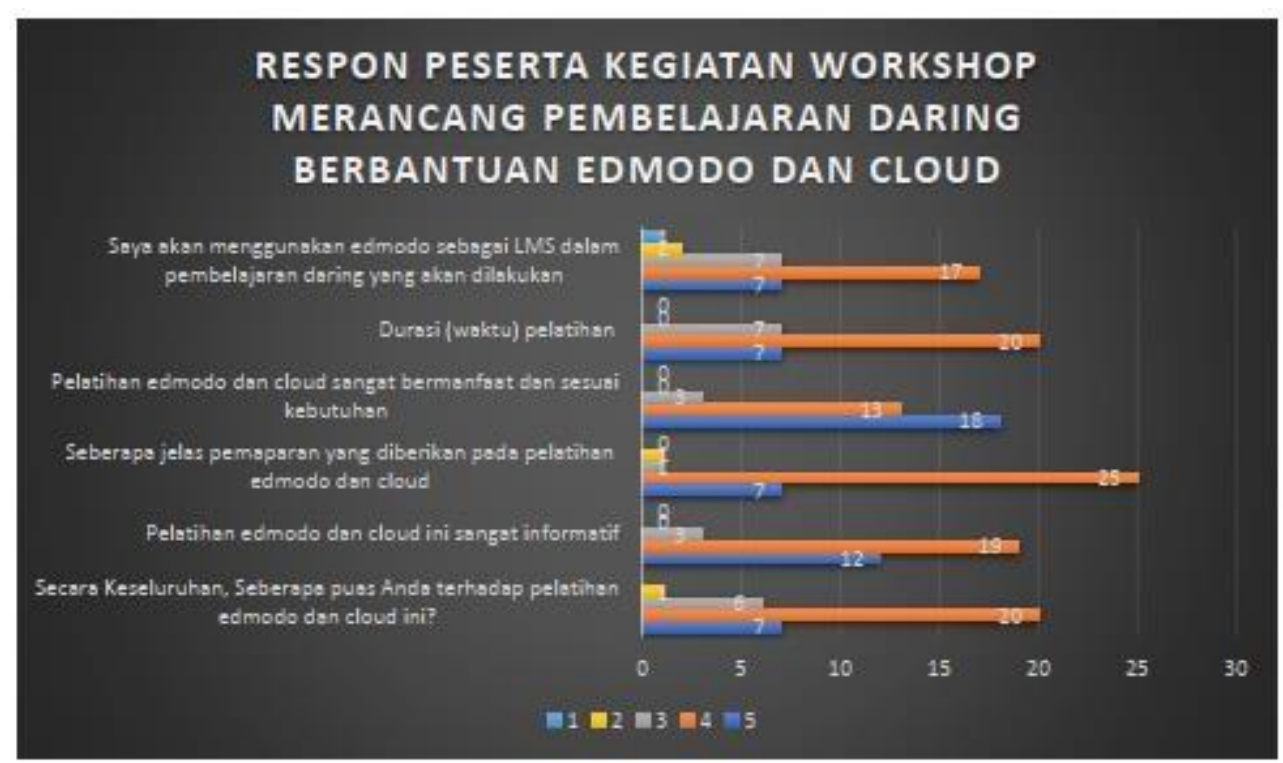

Gambar 3. Hasil angket peserta workshop

Berdasarkan gambar diatas, terlihat bahwa hampir semua peserta merasa puas dengan kegiatan workshop yang dilakukan. Pengelolaan kelas daring menggunakan Edmodo dan cloud dinilai lebih sederhana untuk digunakan serta penyimpanannya pun lebih besar sehingga dapat membantu guru-guru dalam mengorganisasikan tugas-tugas dengan efektif dan efisien. Hal ini terlihat dari respon peserta pelatihan yang menganggap platform Edmodo lebih sederhana dan memiliki penyimpanan yang cukup besar (Gambar 4). Sejalan dengan itu Kongchan (2018) melalui penelitiannya mengungkapkan bahwa guru-guru menyukai edmodo karena kesederhanaan penggunaan, ramah pengguna, dan mendukung sekali dalam pengajaran dan pembelajaran di kelas. Lebih lanjut, hasil penelitian tersebut merekomendasikan setiap guru mampu menggunakan Edmodo sebagai alat atau media dalam mengembangkan kelas komunitas online untuk peserta didik.

\section{Hal positif yang dapat diambil dari pelatihan edmodo dan cloud yang anda ikuti *}

\section{Aplikasi edmodo lebih simple dan penyimpanan lebih besar.}

\section{Gambar 4. Respon peserta pelatihan}

Respon positif dan antusias peserta dalam mempelajari Edmodo sangatlah besar. Hal ini sejalan dengan hasil penelitian oleh Thongmak tahun 2013 yang Sebagian besar respondennya berpendapat bahwa Edmodo sangat nyaman digunakan salah satunya karena tampilannya seperti social media yaitu Facebook Respon positif dari peserta pelatihan ditandai dengan respon angket salah satu peserta yang menginginkan adanya pendampingan secara terus menerus dalam mengelola kelas daring menggunakan Edmodo (Gambar 5). Hal ini tentu baik dilakukan mengingat bahwa setiap pendidik perlu mengembangkan kompetensinya terutama dalam penggunaan IT dalam menyampaikan ilmu atau pengetahuan. 
JURNAL ANUGERAH, November 2020; Vol 2(2): 101 - 108

e-ISSN 2715-8179

Saran dan Masukan Peningkatan perbaikan pelatihan edmodo dan cloud kedepan *

Terus ada pendampingan

\section{Gambar 5. Respon peserta pelatihan}

Lebih dari $75 \%$ dari seluruh peserta pelatihan telah dapat membuat kelas pada Edmodo dan merancang pembelajaran daring dengan cukup baik. Hal ini terlihat dari beberapa hasil kelas yang dibuat oleh peserta yang memuat postingan yang dilengkapi dengan sapaan, penjelasan aktivitas pembelajaran, sumber belajar seperti dari youtube yang relevan atau bahkan slide presentasi yang dibuat sendiri dan disimpan dalam penyimpanan internal Edmodo atau library (Gambar 6).

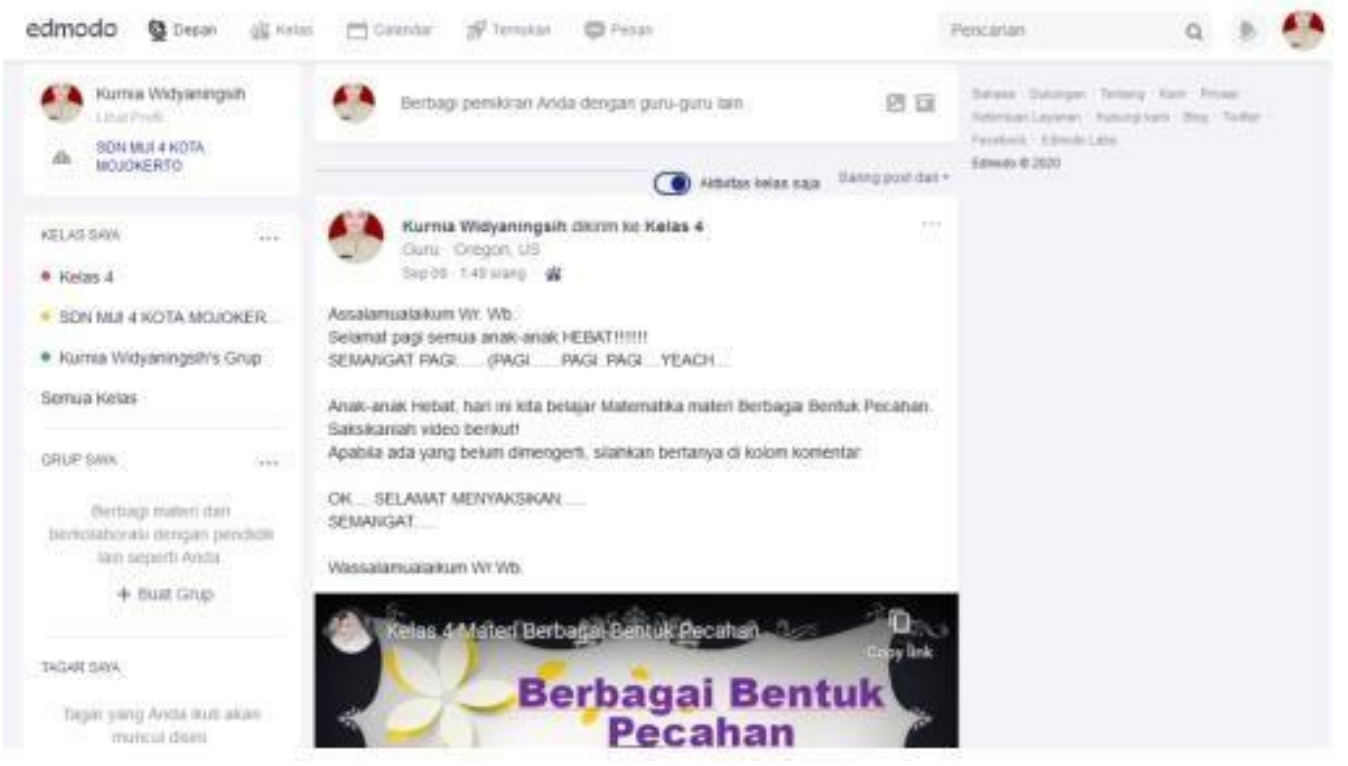

Gambar 6. Contoh kelas Edmodo dari peserta pelatihan

Selain itu, guru-guru peserta pelatihan juga sudah mampu membuat tugas / assignment dan kuis /quiz sebagai salah satu instrument yang dapat digunakan ketika mereka melaksanakan pembelajaran daring Bersama-sama dengan peserta didik (Gambar 7). Tugas dan kuis merupakan dua instrument assessment yang sering digunakan oleh guru terutama pada masa pandemi untuk dapat mengukur ketercapaian tujuan pembelajaran. Penggunaan Edmodo pada dua hal tersebut terkait evaluasi membuat pemberian tugas hingga penilaian menjadi lebih cepat dan mudah (Balasubramanian et al., 2014). 


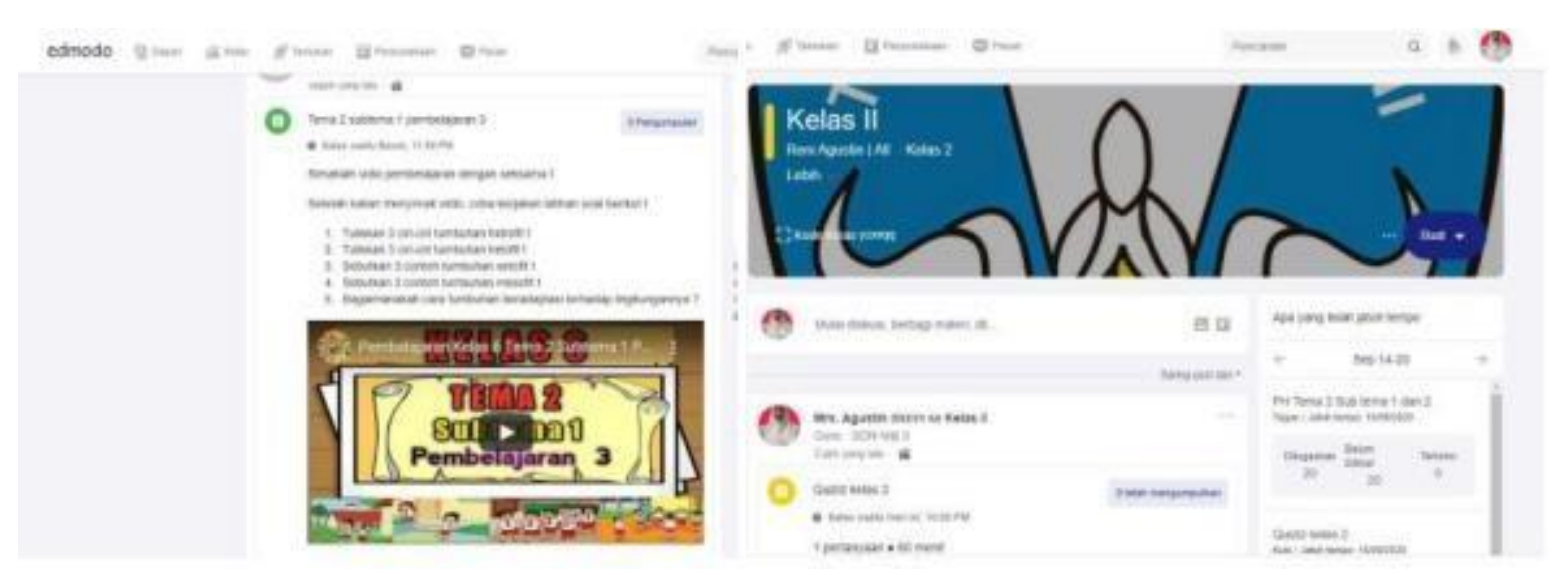

Gambar 7 . Contoh kelas Edmodo dari peserta pelatihan

Pada saat pelaksanaan pelatihan, terdapat beberapa faktor yang mendukung dan menghambat terlaksananya kegiatan. Faktor pendukung tersebut yaitu komunikasi antar tim yang efektif. Hal ini karena seluruh tim melaksanakan kegiatan pada tempat yang sama dengan mematuhi protokol kesehatan sehingga koordinasi dalam setiap pelaksanaan menjadi efektif dan efisien. Selain itu, faktor penghambat dalam pelaksanaan pengabdian ini adalah koneksi internet pada setiap peserta. Hal ini ditandai dengan beberapa peserta yang tidak bisa mendengar dengan baik atau hingga keluar masuk pelatihan online. Namun, kendala ini terjadi untuk Sebagian kecil peserta saja dan pelatihan yang dilaksanakan ini terekam dan di unggah pada akun youtube sehingga peserta dapat melihat kembali penjelasan yang telah diberikan.

\section{Kesimpulan}

Workshop yang telah dilakukan memberikan dampak yang positif dan bermanfaat bagi guru-guru Sekolah dasar di Krangga Mojokerto. Hal tersebut dapat terlihat dari 1) adanya peningkatan pengetahuan mengenai salah satu LMS yaitu edmodo sebagai salah satu alternatif dalam memberikan pembelajaran kepada siswa; 2) keterampilan guru dalam merancang pembelajaran daring menggunakan edmodo dan cloud meningkat. Hal ini dapat terlihat dari hasil rancangan pembelajaran yang telah dibuat oleh guru pada LMS edmodo; 3) antusiasme guru-guru dalam mengikuti workshop merancang pembelajaran online dengan edmodo dan cloud ini terlihat sangat tinggi sebagaimana sudah dipaparkan pada hasil.

\section{Saran}

Workshop merancang pembelajaran daring berbantuan edmodo dan cloud berjalan dengan baik dan sistematis. Sebagian besar peserta merasa workshop ini sangat bermanfaat dan berguna bagi pelaksanaan tugas mengajar peserta. Namun, hendaknya pelatihan ini dilaksanakan secara periodik atau berkala karena hal tersebut akan memberikan pengetahuan yang mendalam untuk merancang pembelajaran daring, disisi lain perkembangan teknologi yang cukup cepat membuat setiap guru harus mampu mengembangkan kompetensinya terutama penggunaan IT oleh karena itu program sejenis workshop ini perlu untuk dilakukan secara berkesinambungan.

\section{Ucapan Terima Kasih}

Penulis mengucapkan terima kasih kepada pihak Fakultas Matematika dan Ilmu pengetahuan Alam (FMIPA) UNESA yang telah memberikan dukungan moral maupun materiil pada program pengabdian kepada masyarakat ini sehingga program dapat berjalan dengan bak. 
JURNAL ANUGERAH, November 2020; Vol 2(2): 101 - 108 e-ISSN 2715-8179

Alhawiti, M M., \& Abdelhamid, Y. (2017). A personalized e-learning framework. Journal of Education and e-Learning Research, 4(1), 15-21.

Astuti, P., \& Febrian. (2019). Diseminasi online multimedia pembelajaran matematika yang dikembangkan menggunakan videoscribe. Jurnal Anugerah,, 1(1), 19-24.

Ariani, Y., Helsa, Y., Ahmad, S., \& Prahmana, R. C. I. (2017, December). Edmodo social learning network for elementary school mathematics learning. Journal of Physics: Conference Series 943(1).

Balasubramanian, K., Jaykumar, V., \& Fukey, L. N. (2014). A study on "Student preference towards the use of Edmodo as a learning platform to create responsible learning environment". Procedia-Social and Behavioral Sciences, 144(1), 416-422.

Crawford, J., Butler-Henderson, K., Rudolph, J., Malkawi, B., Glowatz, M., Burton, R., \& Lam, S. (2020). COVID-19: 20 countries' higher education intra-period digital pedagogy responses. Journal of Applied Learning \& Teaching, 3(1), 1-20.

Evenddy, S. S. \& Hamer,W. (2016). Edmodo as a media to teach vocabulary. The Journal of English Language Studies, 1(1), 26-34.

Joksimovic, S., etc.(2017). How do we model learning at scale? a systematic review of research on MOOCs. Review of Educational Research, 88(1), 43-86.

Kongchan, C. (2008). How a non-digital-native teacher makes use of Edmodo. Proceedings of the 5th Intenational Conference ICT for Language Learning. Florence.

Panyajamorn,T., Suanmali, S., Kohda, Y., Chongphaisal, P., \& Supnithi, T. (2018). Effectiveness of elearning design and affecting variables in Thai public schools. Malaysian Journal of Learning and Instruction, 15(1), 1-34.

Surat Edaran Mendikbud Nomor 3 Tahun 2020 tentang Pencegahan COVID-19 pada Satuan Pendidikan. (2020a, Maret 9). Retrieved from http://pgdikmen.kemdikbud.go.id/read-news/suratedaran-mendikbud-nomor-3-tahun-2020

Surat Edaran Mendikbud Nomor 3 Tahun 2020 tentang Pencegahan COVID-19 pada Satuan Pendidikan. (2020b, Maret 24). Retrieved from http://pgdikmen.kemdikbud.go.id/read-news/suratedaran-mendikbud-nomor-4-tahun-2020

Surat Edaran Mendikbud Nomor 36962/MPK.A/HK/2020 tentang Pembelajaran secara Daring dan Bekerja dari Rumah dalam Rangka Pencegahan Penyebaran Corona Virus Disease (COVID19). (2020c, Maret 17). Retrieved from http://1ldikti14.ristekdikti.go.id/assets/berkas/e4ac36b3906ce2044c95ed82cc0064e3.pdf

Thongmak, M. (2013). Social network system in classroom: Antecedents of Edmodo@ adoption. Journal of E-learning and Higher Education, 2013(1), 1-15.

Trust, T. (2017). Motivation, empowerment, and innovation: Teachers' beliefs about how participating in the Edmodo math subject community shapes teaching and learning. Journal of Research on Technology in Education, 49(1-2), 16-30.

Widyanuratikah, I. (2020). Belajar dari rumah, konsep yang ternyata tak mudah. Retrieved from https://republika.co.id/berita/q7ds30328/belajar-dari-rumah-konsep-yang-ternyata-tak-mudah

Widyo, D. (2020). Corona dan belajar atau sekolah daring. https://www.kompasiana.com/mazdik/5e732d3f097f364c524e8042/korona-dan-belajarsekolah-daring 